\title{
Widening the geographical distribution of Pimelodus mysteriosus Azpelicueta 1998 (Siluriformes: Pimelodidae) to the upper Paraná River, with diagnosis for syntopic congeners
}

\author{
Gabriel de Carvalho Deprá ${ }^{1,4}$ Renata Rúbia Ota ${ }^{1}$, Fagner de Souza ${ }^{1}$, Weferson Júnio da Graça ${ }^{2,3}$ \& \\ Carla Simone Pavanelli, ${ }^{1,3}$
}

\author{
${ }^{1}$ Universidade Estadual de Maringá, Programa de Pós-Graduação em Ecologia de Ambientes Aquáticos \\ Continentais, Av. Colombo, 5790, 87020-900 Maringá, PR, Brazil. \\ ${ }^{2}$ Universidade Estadual de Maringá, Centro de Ciências Biológicas, Departamento de Biologia, Programa \\ de Pós-Graduação em Biologia Comparada, Av. Colombo, 5790, 87020-900 Maringá, PR, Brazil. \\ ${ }^{3}$ Universidade Estadual de Maringá, Núcleo de Pesquisas em Limnologia, Ictiologia e Aquicultura, \\ Av. Colombo, 5790, 87020-900 Maringá, PR, Brazil. \\ ${ }^{4}$ Corresponding author: Gabriel de Carvalho Deprá, e-mail: gabrieldepra@gmail.com
}

DEPRÁ, G.C., OTA, R.R., SOUZA, F., GRAÇA, W.J., PAVANELLI, C.S. Widening the geographical distribution of Pimelodus mysteriosus Azpelicueta 1998 (Siluriformes: Pimelodidae) to the upper Paraná River, with diagnosis for syntopic congeners. Biota Neotropica. 15(3): e20140124. http://dx.doi.org/10.1590/ 1676-06032015012414

\begin{abstract}
Pimelodus mysteriosus Azpelicueta 1998, previously known only from the lower Paraná and Paraguay River basins, has been also recorded in the upper Paraná River floodplain. The only congeners occurring in syntopy with $P$. mysteriosus in the upper Paraná River basin are $P$. maculatus and P. ornatus. New diagnostic characters between P. mysteriosus and P. maculatus are provided.
\end{abstract}

Keywords: Canal da piracema, Invasive species, Itaipu, Non-native species, Taxonomy.

DEPRÁ, G.C., OTA, R.R., SOUZA, F., GRAÇA, W.J., PAVANELLI, C.S. Ampliando a distribuição geográfica de Pimelodus mysteriosus Azpelicueta 1998 (Siluriformes: Pimelodidae) para a bacia do alto rio Paraná, com diagnose para congêneres sintópicas. Biota Neotropica. 15(3): e20140124. http://dx.doi.org/10. 1590/1676-06032015012414

Resumo: Pimelodus mysteriosus Azpelicueta 1998, previamente conhecida apenas das bacias do baixo rio Paraná e do rio Paraguai, foi também registrada na planície de inundação do alto rio Paraná. As únicas congêneres que ocorrem em sintopia com $P$. mysteriosus na bacia do alto rio Paraná são P. maculatus e $P$. ornatus. Novos caracteres diagnósticos entre P. mysteriosus e P. maculatus são fornecidos.

Palavras-chave: Canal da piracema, Espécies invasoras, Espécies não nativas, Itaipu, Taxonomia.

\section{Introduction}

Pimelodus mysteriosus Azpelicueta 1998 was described, based on 179 specimens (mostly below $100.0 \mathrm{~mm} \mathrm{SL}$, maximum $143.2 \mathrm{~mm} \mathrm{SL}$ ), from the stretch of the lower Paraná River basin comprised between the mouth of the Iguaçu River and little downstream of the mouth of the Paraguay River. In the original description, two specimens from the upper Paraguay River basin (MZUSP 44403, 76.2 and $111.0 \mathrm{~mm} \mathrm{SL}$, not examined here), in the municipality of Cáceres, Mato Grosso State, were also assigned to that species. Azpelicueta (1998) did not mention any other specimen from the Paraguay River basin, leaving a geographic gap between the aforementioned specimens and the specimens from the lower Paraná River basin. Additional records of the species in the Paraguay River basin were made by Souza-Filho \& Shibatta (2007) who reported P. mysteriosus from the Cuiabá and Miranda River basins, Mato Grosso and Mato Grosso do Sul States, respectively. Meanwhile, no records have been made of this species in the Paraná River basin, upstream of the mouth of the Iguaçu River, meaning that it has been considered absent in the upper Paraná River basin.

In the main channel of the Paraná River, upstream of the mouth of the Iguaçu River is the Itaipu Dam. Between 1982, when its dam was concluded, and December 2002, when the Canal da Piracema was opened, it would be considered as the inferior boundary of the upper Paraná River basin, working as a barrier avoiding fish dispersion between the lower and the upper portions of the basin. Before 1982, the lower limit of the upper Paraná River basin was the Sete Quedas, a complex of falls that also worked as an effective barrier to fish dispersion until it was submersed by the Itaipu Reservoir. Initially, therefore, the dam caused the mixture of the upper and lower Paraná River basin fish faunas, because the filling of the reservoir worked as a lift, allowing some species to overcome the Sete Quedas falls barrier and to establish themselves in the upper Paraná River basin (Petry et al. 2003, 
Agostinho et al. 2007, Langeani et al. 2007, Júlio Jr. et al. 2009). Since 2002, the Canal da Piracema, a fish pass system, has allowed the dispersion of even more fish species (Makrakis et al. 2007), both upwards and downwards.

The stretch between the Itaipu Reservoir and the dam of the hydroelectric power plant Engenheiro Sérgio Motta (also called Porto Primavera) upstream is the last lotic stretch of the Paraná River in Brazilian territory (Agostinho et al. 2004). The right bank of that stretch is bordered by the upper Paraná River floodplain, characterized by possessing many biotopes (backwaters, canals, rivers and lagoons with or without permanent connection to a river, among others). The Núcleo de Pesquisas em Limnologia, Ictiologia e Aquicultura (Nupélia), of the Universidade Estadual de Maringá, has been collecting in the upper Paraná River floodplain since 1986. Since then, mainly after year 2000, Nupélia staff has captured many specimens of Pimelodus, some of which housed in the Coleção Ictiológica do Nupélia, that do not belong to any of the species previously reported in the upper Paraná River basin (see Langeani et al. 2007). They have been identified as $P$. mysteriosus based on the following characters pointed out by Azpelicueta (1998): (1) three or four rows of spots along the sides of the body; (2) long maxillary barbel frequently reaching beyond the caudal-fin base; (3) exposed surface of supraneural and $1^{\text {st }}$ and $2^{\text {nd }}$ dorsal pterygiophores broad; (4) anterior margin of pectoral spines with well-developed serration; (5) teeth present on vomer and metapterygoid in most individuals.
Thereby, the scope of this study was to extend the current geographic distribution of Pimelodus mysteriosus obtained through these new records, as well as to provide more information about the species diagnosis relative to syntopic species from the newly recorded locality.

\section{Material and methods}

Examined material includes 19 specimens of Pimelodus mysteriosus captured in several newly recorded localities mostly within the upper Paraná River floodplain (Fig. 1) and four paratypes of $P$. mysteriosus. A complete list of material examined is provided in Appendix 1. The following measurements were taken from all specimens: (1) standard length; (2) head length (from tip of snout to posterior margin of opercle, not including fleshy opercular membrane); (3) snout length (from tip of snout to anterior margin of orbit), (4) interorbital distance (shortest distance between bony orbital margins); (5) eye diameter. Pairwise regression analyses were performed on Microsoft ${ }^{\mathbb{R}}$ Excel $^{\mathbb{R}}$ between all measurements in order to evaluate their usefulness in distinguishing $P$. mysteriosus.

\section{Results and discussion}

Pimelodus mysteriosus was found in syntopy with two congeners within the upper Paraná River basin: $P$. maculatus Lacepède and $P$. ornatus Kner. Pimelodus mysteriosus is readily

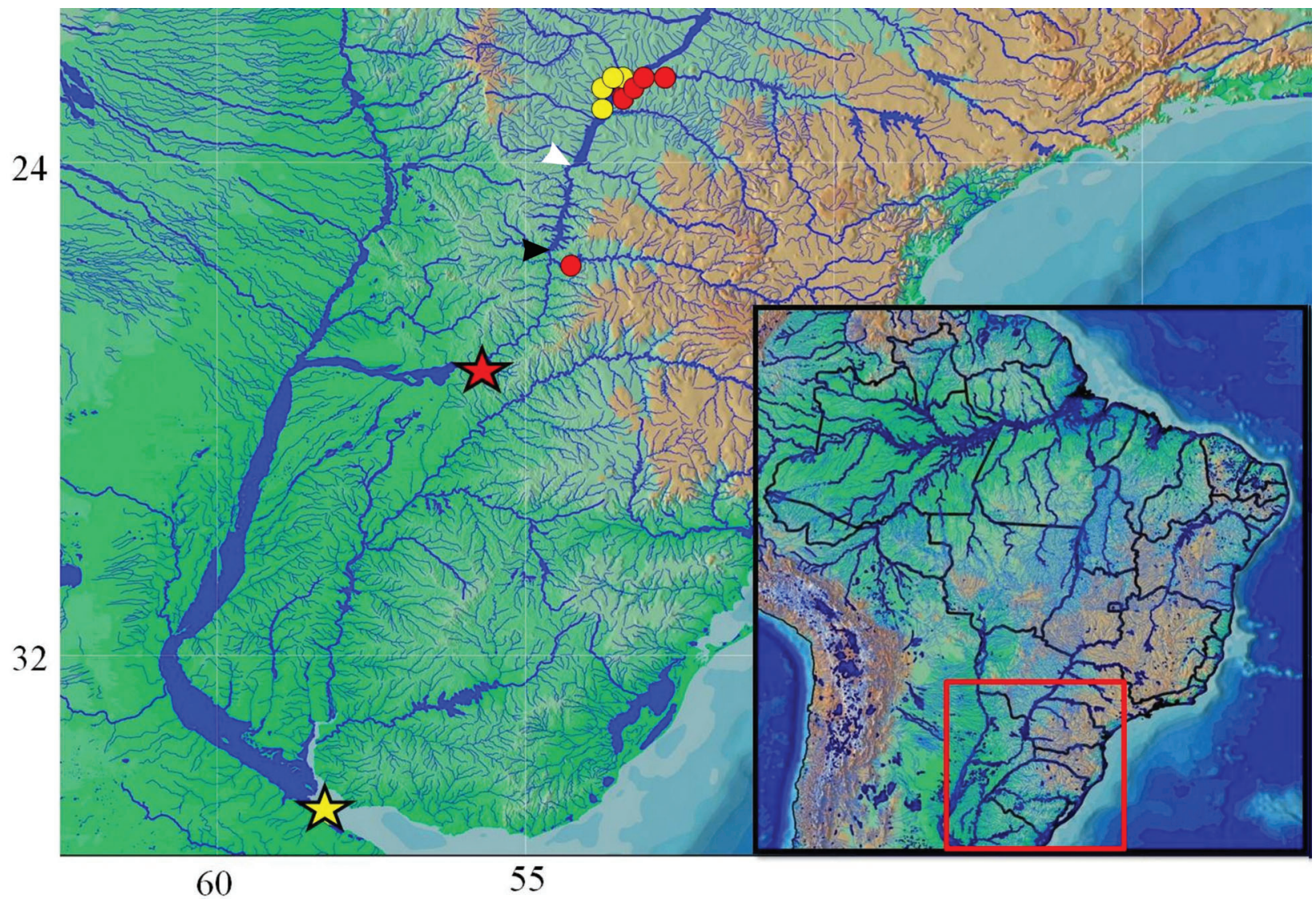

Figure 1. Geographic distribution of examined specimens of Pimelodus maculatus and P. mysteriosus. The white arrow indicates the locality of the former Sete Quedas falls; the black arrow indicates the locality of the Itaipu Dam. The yellow circle represents $P$. maculatus and the yellow star its type locality; red circle represents the new distribution of $P$. mysteriosus and the red star its type locality. One symbol may represent more than one locality. 


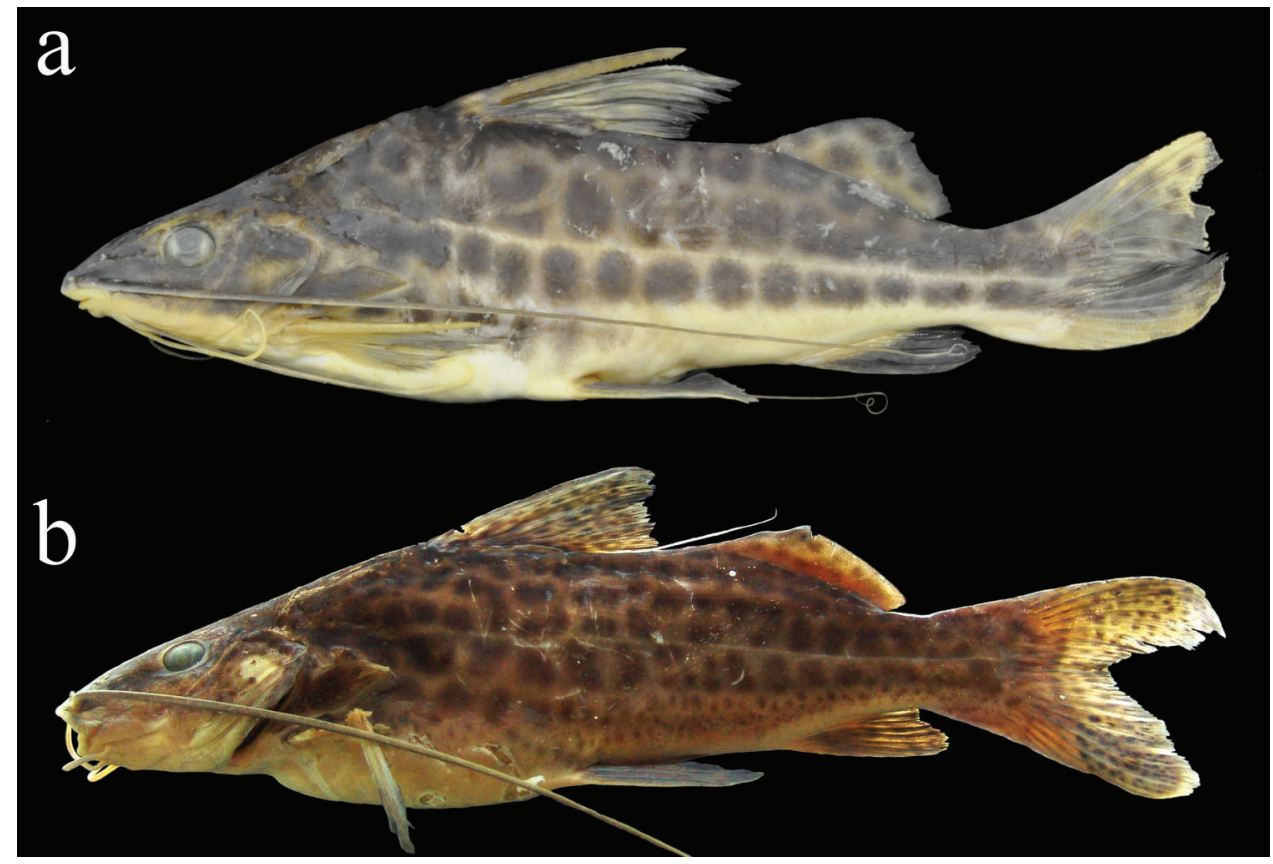

Figure 2. Lateral view of (a) Pimelodus mysteriosus, NUP 10824, $160.0 \mathrm{~mm} \mathrm{SL}$, and (b) P. maculatus, NUP 12783, $214.4 \mathrm{~mm}$ SL, evidencing color pattern in alcohol and shape of adipose fin. Photograph (a) by Celso Ikedo.

distinguished from $P$. ornatus, and also from $P$. argenteus Perugia and $P$. albicans (Valenciennes) (both sympatric with $P$. mysteriosus in the lower Paraná River basin), by the spotted body (Fig. 2a) (vs. striped in P. albicans and P. ornatus and uniformily greyish in $P$. argenteus). Pimelodus brevis, until recently considered as valid in the lower Paraná River basin, has been synonymized in P. argenteus by Rocha \& Pavanelli (2014).

Pimelodus mysteriosus differs from $P$. maculatus by having: (1) long maxillary barbel, frequently reaching beyond base of caudal fin in adult specimens (vs. not reaching base of anal fin); (2) exposed surface of supraneural and $1^{\text {st }}$ and $2^{\text {nd }}$ dorsal pterygiophores broad ( $v$ s. narrow); (3) anterior margin of pectoral spines with well-developed serration ( $v s$. poorly developed); (4) teeth present in vomer and metapterygoid in all individuals (vs. absent from both bones in all individuals). We observed some other diagnostic characters of P. mysteriosus not mentioned by Azpelicueta (1998), such as adipose fin short, deep and somewhat triangular in shape (Fig. 2a), vs. long, its depth about half its length

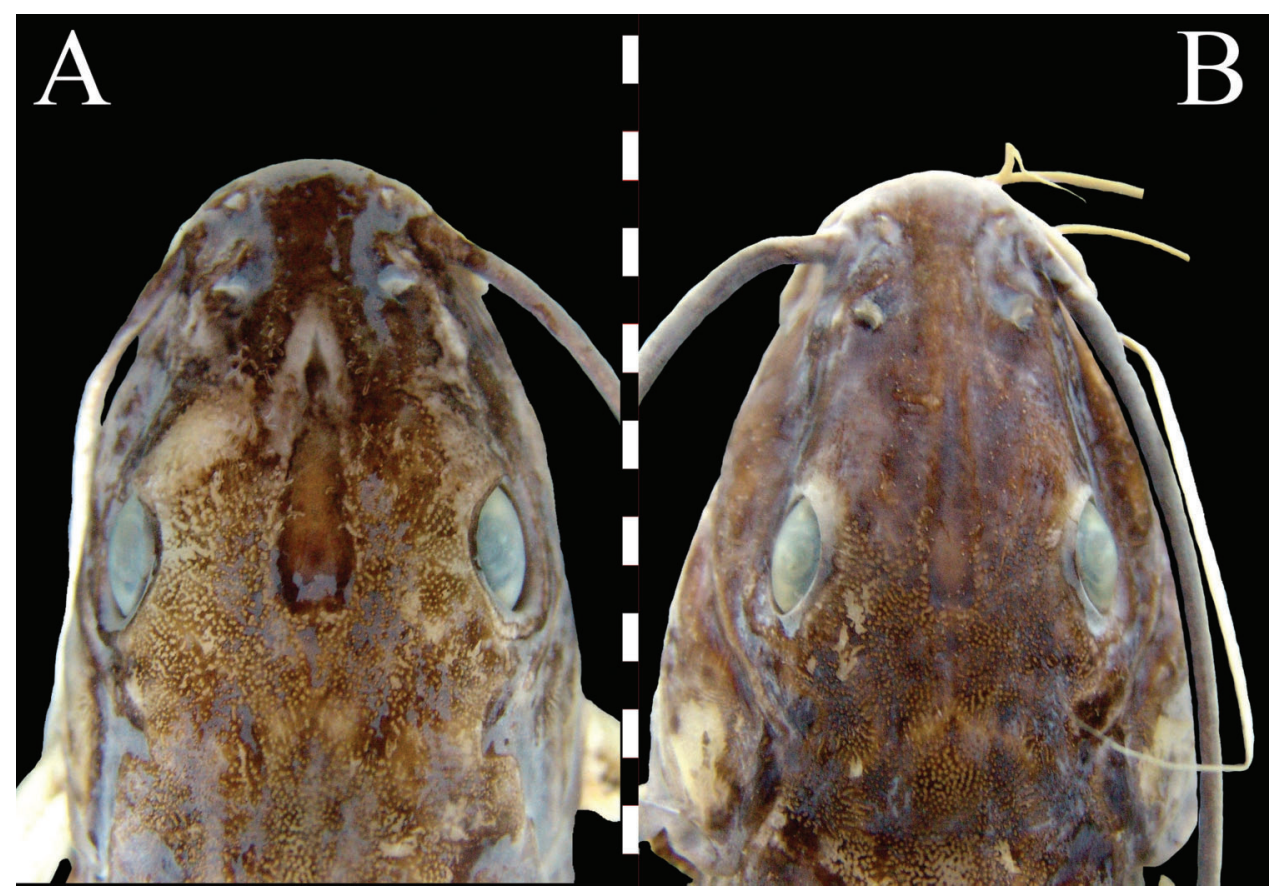

Figure 3. Dorsal view of head, evidencing interorbital distance in (a) Pimelodus mysteriosus, NUP 12778, $202.5 \mathrm{~mm} \mathrm{SL}$; and (b) P. maculatus, NUP 12783, $214.4 \mathrm{~mm}$ SL. 


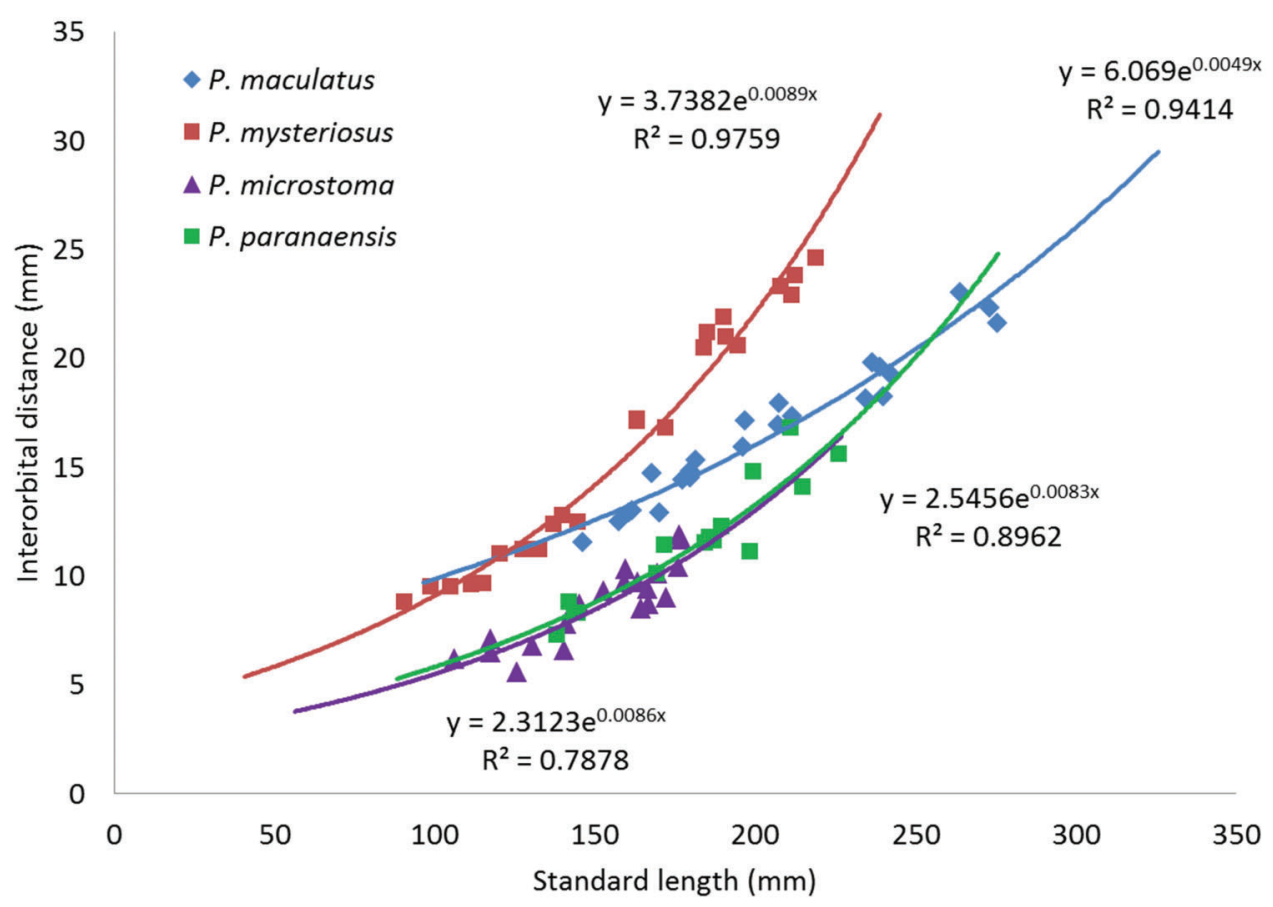

Figure 4. Regression analysis of interorbital distance in Pimelodus maculatus $(\mathrm{N}=23)$, P. microstoma $(\mathrm{N}=21), P$. mysteriosus $(\mathrm{N}=23)$ and $P$. paranaensis $(\mathrm{N}=15)$ from the upper Paraná River basin.

in P. maculatus (Fig. 2b) and also in P. microstoma Steindachner and $P$. paranaensis Britski \& Langeani, both sympatric species in the upper Paraná River basin. Also, the regression analyses and the measurement ranges showed that $P$. mysteriosus can be distinguished from sympatric species in the upper Paraná River basin by the interorbital distance (Figs. 3, 4; Table 1). Furthermore, live specimens of $P$. mysteriosus examined here showed a silvery pigmentation all over the body, partially hiding the dark spots of the flanks. Pimelodus maculatus, in contrast, did not present silvery pigmentation, but an intense yellow coloration, due to the presence of that pigment in its body mucus. A yellow pigmentation may be present also in P. mysteriosus, as stated by Azpelicueta (1998: 91) and Azpelicueta et al. (2008: 159), but in individuals analyzed herein it was never as strong as in P. maculatus.

As mentioned before, both the filling of the Itaipu Reservoir and the opening of the Canal da Piracema were responsible for the dispersion, followed in some cases by the establishment into the upper Paraná River basin of some species previously unable to overcome the Sete Quedas falls (Júlio Jr. et al. 2009; Agostinho et al. 2015). Any of those or both events may have caused the occurrence of Pimelodus mysteriosus in the upper Paraná River floodplain, despite of all specimens hosted in the NUP collection having been captured after 2002 (year of the opening of the Canal da Piracema).

\section{Appendix 1}

\section{Material examined}

Pimelodus maculatus. Brazil. All from the upper Paraná River basin, collected by Nupélia's team. Mato Grosso do Sul State. NUP 3977, 1, $212.8 \mathrm{~mm}$ SL, Onça Lagoon, tributary to

Table 1. Morphometrics of Pimelodus maculatus $(\mathrm{N}=23)$, P. microstoma $(\mathrm{N}=21)$, P. mysteriosus $(\mathrm{N}=23)$ and $P$. paranaensis $(\mathrm{N}=15)$ captured in the upper Paraná River basin. Efficient measurements in diagnosing $P$. mysteriosus are bolded.

\begin{tabular}{|c|c|c|c|c|}
\hline & P. mysteriosus & P. maculatus & P. microstoma & $P$. paranaensis \\
\hline \multirow[t]{2}{*}{ Standard length $(\mathrm{mm})$} & $90.4-218.7$ & $146.2-275.6$ & $106.2-176.9$ & $138.1-225.8$ \\
\hline & \multicolumn{4}{|c|}{$\%$ of Standard length } \\
\hline Head length & $25.7-29.9$ & $27.0-30.2$ & $25.5-28.0$ & $28.7-30.7$ \\
\hline \multirow[t]{2}{*}{ Interorbital distance } & $8.4-11.5$ & $7.6-8.8$ & $4.5-6.7$ & $5.3-8.0$ \\
\hline & \multicolumn{4}{|c|}{$\%$ of Head length } \\
\hline Snout length & $43.7-50.9$ & $42.7-50.3$ & $44.5-50.9$ & $44.9-49.4$ \\
\hline Interorbital distance & $29.8-40.6$ & $26.4-30.4$ & $16.7-25.3$ & $18.3-27.3$ \\
\hline \multirow[t]{2}{*}{ Eye diameter } & $17.1-30.3$ & $16.8-22.2$ & $21.3-27.7$ & $17.4-23.2$ \\
\hline & \multicolumn{4}{|c|}{$\%$ of Snout length } \\
\hline Interorbital distance & $63.2-80.8$ & $56.9-63.1$ & $36.6-56.0$ & $39.0-55.8$ \\
\hline
\end{tabular}


Baía River, 22³9'48.4"S53¹2'1.6”W, 18 Mar 2011. NUP 3984, 1, $271.4 \mathrm{~mm} \mathrm{SL}$, Patos Lagoon, tributary to Ivinhema River, 2249'33"S5333'09'W, 14 Sep 2011. NUP 6659, 1,

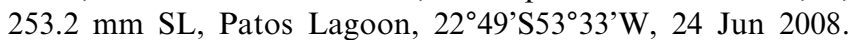
NUP 8637, 2, 204-258 mm SL, Garças Lagoon, 2243'27''S53 13'07'W, 17 Sep 2009. NUP 12111, 1, 228.9 mm SL, Cortado Channel, 22 $48^{\circ} 43^{\prime \prime S} 53^{\circ} 22^{\prime} 40^{\prime \prime} \mathrm{W}, 06$ Dec 2010. NUP 12112, 1, $159.4 \mathrm{~mm}$ SL, Pousada das Garças Lagoon, 22 ${ }^{\circ} 42^{\prime} 1^{\prime \prime S} 53^{\circ}$ 15'23”W, 05 Dec 2010. NUP 12432, 3, 154.6-202 mm SL, Ventura Lagoon, 2251'23'S53'36'01'W, 10 Jun 2011. NUP 12443, 2, 174.4-268.2 mm SL, Patos Lagoon, 22 49'33"S53 33'9'W, 08 Jun 2011. NUP 12781, 1, $178.2 \mathrm{~mm} \mathrm{SL}$, Sumida Lagoon, 22 46'54”S53'29'22”'W, 17 Sep 2011. NUP 12783, 1, 214.4 mm SL, 22³9'48”S53¹2'1.6”W, 18 Mar 2011. Paraná State. NUP 11311, 2, 159.8-270.1 mm SL, Paraná River, $22^{\circ}$ 45'S53 ${ }^{\circ} 17^{\prime} \mathrm{W}, 06$ Mar 2005. NUP 12107, 3, 136.4-231.8 mm SL, Garças Lagoon, 2243'27"S53 13 '4"W, 6 Dec 2010. NUP 12109, 1, $173.6 \mathrm{~mm} \mathrm{SL}$, Pau Véio Lagoon, 2244'50"S53 15'11"W, 06 Dec 2010.

Pimelodus microstoma. Brazil. All from the upper Paraná River basin. Paraná State. NUP 3874, 1, 105.5 mm SL, Pirapó River, 2319'36"S51 50'41"W, 17 Sep 2004, Nupélia. NUP 7505, 1, 106.2 mm SL, Pitangui River, 2452'22'S50¹5’08'W, 06 May 2007, A. M. Gealh. NUP 7781, 3, 118.5-179.4 mm SL, Pitangui River, 24 $52^{\prime} 22^{\prime}$ 'S50 $50^{\circ} 15^{\prime}$ "W, 06 Jan 2007, A. M. Gealh. NUP 9745, 6, 122.7-162.8 mm SL, Pitangui River, 24 52'22”'S50¹5'08'W, 14 Apr 2007, A. M. Gealh. NUP 9816, 2, 154.6-183.6 mm SL, Pitangui River, 2450’45”'S50¹7'16”'W, 06 May 2007, A. M. Gealh. NUP 10649, 4, 128.1-157.0 mm SL, Bonito River, 2445'30"S51 24'49”W, 23 May 2009, D. Viana. NUP 11000, 1, $146.0 \mathrm{~mm} \mathrm{SL}$, Canal da Piracema, $25^{\circ}$ 06'03”S54³4'51'W, 19 May 2005, GETECH. NUP 14941, 6, 107.5-177.0 mm SL, Piquiri River, 2456'54'S 52³5'49'”, 12 Sep 2012, V. P. Margarido et al. NUP 15312, 2, 106.3-126.2 mm SL, Cantu River, $24^{\circ} 43^{\prime}$ S52 ${ }^{\circ} 18^{\prime} \mathrm{W}$, 09 Sep 2010, GERPEL. NUP 11375, 1, $167.5 \mathrm{~mm}$ SL, Pitangui River, 2450'58'S50 17'13”W, 06 Jun 2007, A. M. Gealh.

Pimelodus mysteriosus. Argentina. Missiones State. MLP 9194, 2 paratypes, 115.1-127.2 mm SL, Paraná River close to the mouth of the Iguaçu River, Nov 1986, M. M. Azpelicueta et al. MLP 9195, 2 paratypes, 111.2-132.5 mm SL, Oro Verde, Paraná River, Oct 1985, O. García et al. Brazil. All from the upper Paraná River basin and collected by Nupélia's team, except when noted otherwise. São Paulo State. NUP 6334, 1, 118.6 mm SL, Rosana Reservoir, 22³6'01'S52 52'20”W, Jan 2007. Mato Grosso do Sul State. NUP 10824, 2, 158.0-160.0 mm SL, Guaraná Lagoon, 22 43'17"S5318'09"W, 18 Sep 2010. NUP 12110, 3, 101.8-175.3 mm SL, Ventura Lagoon, $22^{\circ}$ 51'23"S53 36'1"W, 02 Dec 2010. NUP 12113, 1, $86.2 \mathrm{~mm}$ SL, Ivinhema River, 2247'59"S53³2'21'W, 30 Nov 2010. NUP 12438, 2, 169.1-184.4 mm SL, Peroba Lagoon, 2254'30"'S53 38'24”W, 10 Jun 2011. NUP 12441, 1, 199.9 mm SL, Onça Lagoon, 22³9'48"S53'12'2"'W, 11 Jun 2011. NUP 12778, 1, 202.5 mm SL, Gavião Lagoon, 22 40 '48”S53 ${ }^{\circ} 13$ '53"W, 19 mar 2011. NUP 12782, 1, $212.9 \mathrm{~mm} \mathrm{SL}$, Peroba Lagoon, $22^{\circ}$ 54’30"S 5338'24'W, 16 Sep 2011. NUP 12785, 1, $211.3 \mathrm{~mm}$ SL, Baía Channel, 2241'26'S53¹3'29"W, 18 Mar 2011. NUP 13630, 1, $139.3 \mathrm{~mm}$ SL, Finado Raimundo Lagoon, 2247'40”S 5332'1"W, 15 Mar 2012. NUP 13633, 1, $212.1 \mathrm{~mm} \mathrm{SL}$, Ventura Lagoon, 2251'24"S5336'01'W, 14 Mar 2012. Paraná State. NUP 12108, 1, $140.3 \mathrm{~mm}$ SL, Garças Lagoon, $22^{\circ}$ 43'27'S5313'4"W, 6 Dec 2010. NUP 16111, 1, 36.9 mm SL,
Iguaçu River, 25³9'02”S; 54²7’25”W, 09 Oct 2013, V. P. Margarido et al.

Pimelodus paranaensis. Brazil. All from the Corumbá River, upper Paraná River basin, collected by Nupélia's team. Goiás State. NUP 5798, 3, 207.0-223.0 mm SL, 22 Aug 1997. NUP 5814, 1, 147.0 mm SL, 17²3'37'S48³2'54'W, 18 Oct 1996. NUP 5823, 3, 180.0-190.0 mm SL, 13 Jul 1996. NUP 5824, 4, 85.0-149.0 mm SL, 23 Sep 1996. NUP 5829, 1, 186.0 mm SL, 13 Jan 1999. NUP 5831, 2, 140.0-202.0 mm SL, 16 Jul 1996. NUP 5832, 1, $225.0 \mathrm{~mm}$ SL, 06 Apr 1999. NUP 5837, 1, $185.0 \mathrm{~mm}$ SL, 11 Aug 1998.

\section{Acknowledgments}

Thanks are due to Nupélia staff for collecting the material and providing logistical support and to V. P. Margarido (Unioeste) and colleagues for bringing to Nupélia the specimen captured in the Rio Iguaçu, and to Celso Ikedo (Nupélia) for taking one of the photographs. We are also indebted to the anonymous reviewers that helped improving the paper. The Coordenação de Aperfeiçoamento de Pessoal de Nível Superior (CAPES) provided fellowships for FS. The Conselho Nacional de Desenvolvimento Científico e Tecnológico (CNPq) provided fellowships to GCD and RRO and grants to CSP. The Fundação Araucária (Seti-PR) provided grants to WJG.

\section{References}

AGOSTINHO, A.A., GOMES, L.C., THOMAZ, S.M. \& HAHN, N.S 2004. The upper Paraná River and its floodplain: main characteristics and perspectives for management and conservation. In The upper Paraná river and its floodplain: Physical aspects, ecology and conservation (S.M. Thomaz, L.C. Gomes \& N.S. Hahn, eds.). Backhuys Publishers, Leiden, The Netherlands, p. 381-393.

AGOSTINHO, A.A., PELICICE, F.M., PETRY, A.C., GOMES, L.C. \& JULIO Jr., H.F. 2007. Fish diversity in the upper Paraná River basin: habitats, fisheries, management and conservation. Aquatic Ecosystem Health \& Management 10(2):174-186.

Agostinho, A.A., SUZUKI, H.I., FUGI, R., ALVES, D.C., TONELLA, L., ESPINDOLA, L.A. 2015. Ecological and life history traits of Hemiodus orthonops in the invasion process: looking for clues at home. Hydrobiologia, 746(1):415-430, http://dx.doi.org/10.1007/s10750-014-2030-2.

AZPELICUETA, M. de las M. 1998. A new species of Pimelodus (Siluriformes: Pimelodidae) from the Paraguay and lower Paraná rivers. Neotropica (La Plata) 44(111-112):87-94.

AZPELICUETA, M. de las M., LUNDBERG, J.G. \& LOUREIRO, M. 2008. Pimelodus pintado, a new species of catfish from affluent rivers of Laguna Merín, Uruguay, South America. Proceedings of the Academy of Natural Sciences of Philadelphia 157: 149-162, http://dx.doi.org/10.1635/0097-3157(2008)157[149:PPSPAN] 2.0.CO;2.

JÚlIO Jr., H.F., DEI TÓS, C., AGOSTINHO, A.A. \& PAVANELLI, C.S. 2009. A massive invasion of fish species after eliminating a natural barrier in the upper rio Paraná basin. Neotropical Ichthyology 7(4):709-718, http://dx.doi.org/10.1590/ S1679-62252009000400021.

LANGEANI, F., CORRÊA E CASTRO, R.M., OYAKAWA, O.T., SHIBATTA, O.A., PAVANELLI, C.S. \& CASATTI, L. 2007. Diversidade da ictiofauna do Alto Rio Paraná: composição atual e perspectivas futuras. Biota Neotropica 7(3):181-197, http://dx.doi.org/10.1590/S1676-06032007000300020. 
Deprá, G.C. et al.

MAKRAKIS, S., GOMES, L.C., MAKRAKIS, M.C., FERNANDEZ, D.R. \& PAVANELLI, C.S. 2007. The Canal da Piracema at Itaipu Dam as a fish pass system. Neotropical Ichthyology 5(2):185-195, http://dx.doi.org/10.1590/S1679-62252007000200013.

PETRY, A.C., AGOSTINHO, A.A. \& GOMES, L.C. 2003. Fish assemblages of tropical floodplain lagoons: exploring the role of connectivity in a dry year. Neotropical Ichthyology 1(2):111-119, http://dx.doi.org/10.1590/S1679-62252003000200005.
ROCHA, M.S. \& PAVANELLI, C.S. 2014. Taxonomy of Pimelodus brevis Marini, Nichols \& La Monte, 1933 (Siluriformes: Pimelodidae), an uncertain species from the rio Paraná basin. Neotropical Ichthyology 12(4):755-760, http://dx.doi.org/10.1590/1982-022420140059.

SOUZA-FILHO, H.S. \& SHIBATTA, O.A. 2007. Description of a new species of Pimelodus (Siluriformes, Pimelodidae) from upper rio Paraguai basin. Iheringia, Série Zoologia 97:472-480.

Received 12/08/2014

Revised 24/06/2015

Accepted 27/07/2015 